2. По Э. Избр. произв-ия: В 2 т. - М.: Худож.лит., 1972. т.1, С.177-195.

3. Шелгунов Н.В. Эдгар По, как психолог. Дело. 1874, №7-8, С.350-366.

4. Poe E. LONDON: WILEY \& PUTNAM, 6, WATERLOO PLACE. 1846. C. 64-83

\title{
Языковые средства выражения времени в произведении «Алиса в Стране чудес» Льюиса Кэрролла
}

\author{
Бобоева Д.Н., студентка, \\ Технический институт (филиал) \\ Северо-Восточного федерального университета, \\ 2. Нерюнгри \\ E-mail: dboboeva@mail.ru
}

Научный руководитель: к.филол.н. Павлова Т.Л.

Обращение к проблемам художественного времени со стороны не только литературоведения, но и языкознания продиктовано непреходящим интересом исследователей к способам и средствам организации эстетической действительности произведения и его внутреннего мира, к тексту как художественной и речевой единице и одновременно определенной временно организации, к художественному языку и возможностям его использования в художественном тексте.

В отечественной науке вопросом организации художественного времени определенными языковыми средствами занимались Флоренский П.А., Анненский И.Ф. Фуникова С.В. и др. на материале классических художественных произведений.

Художественная литература, по сравнению с другими видами искусства, максимально свободно обращается с реальным временем. Художественный текст, независимо от того, к какому литературному жанру принадлежит, отражает события, явления или же психическую деятельность человека в их пространственно-временной ориентированности [2].

Художественное время является одной из универсальных составляющих смысловой структуры текста. Оно отражает соотнесенности событий, ассоциативные, причинно-следственные и психологические связи между ними, создает сложный ряд событий, выстраиваемых в ходе сюжетного развертывания произведения. Так оно в художественной литературе обладает определенными свойствами, связанными со спецификой художественного текста, его особенностями и авторским замыслом. Время в тексте может иметь жестко определенные или достаточно размытые границы (события, например, могут охватить десятки лет, год, несколько дней, день, час и т.п.), которые могут обозначаться или, напротив, не обозначаться в произведении по отношений к историческому времени или времени, которое автор устанавливает условно [3, стр. 123-125].

В художественных произведениях часто нарушается реальная последовательность событий, и большую роль играют временные смещения, нарушение временной последовательности, что как раз и затрагивает свойство многомерности произведения и может влиять на авторское деление текста на смысловые отрезки или эпизоды [1, стр.53-65]. Художественное время опирается на следующие средства: систему видо- 
временных форм глагола, их последовательность и противопоставление, транспозицию форм времени; лексические единицы с темпоральной семантикой; падежные формы со значением времени; хронологические пометы; синтаксические конструкции, которые создают определенный временной план; имена исторических деятелей, мифологических героев; номинации исторических событий [2, стр. 126].

Материалом настоящего исследования послужило произведение «Алиса в Стране чудес» Льюиса Кэрролла, известного английского писателя, математика, логика, философа, диакона и фотографа. В произведении повествуется о девочке по имени Алиса, которая попадает сквозь кроличью нору в воображаемый мир, населённый странными антропоморфными существами.

Сказка пользуется устойчивой популярностью как у детей, так и взрослых. Книга считается одним из лучших образцов литературы в жанре абсурда; в ней используются многочисленные математические, лингвистические и философские шутки и аллюзии. Существует немало работ, в которых анализируется художественное пространство произведения, а вот время недостаточно изучено, а потому вызывает особый интерес.

В произведении Льюиса Кэрролла время представлено реальное и ирреальное. Также следует отметить, что автор использует кольцевую композицию. События начала и финала происходят в одном и том же месте, в них участвуют одни и те же герои.

Одним из средств выражения времени в произведении является наречие. В эпизоде, в котором Алиса падает в кроличью нору, автор использует наречие «slowly» c целью создания эффекта замедления. Данный прием помогает автору описать момент погружения в крепкий сон. В этом же эпизоде автор употребляет словосочетание «plenty of time», включающее в себя лексическую единицу с темпоральной семантикой, что так же передает длительность времени [4, стр. 3]. В дальнейшем используются в основном наречия, указывающие на быстроту времени, так как во сне время движется быстрее. Это очень хорошо видно в сцене, когда Алиса начинает уменьшаться благодаря вееру, которым она обмахивалась. Автор употребляет такие наречия, как «rapidly» (быстро), «hastily» (торопливо) и «hurriedly» (поспешно).

Действия в рассказе развиваются достаточно динамично. В моменте, когда Алиса завершает свое долгое падение по кроличьей норе, переход от одной формы времени Past Continuous (was dozing off) к другой форме - Past Perfect (had begun), и далее к форме Past Simple (саme down), усиливает динамику перехода от стадии засыпания к стадии глубокого сна, время, таким образом, ускоряется [4, стр. 6]. Также движение времени показано в следующем примере: «So she was considering in her own mind whether the pleasure of making a daisy- chain would be worth the trouble of getting up and picking the daisies, when suddenly a White Rabbit with pink eyes ran close by her». Здесь происходит переход от временной формы Past Continuous к времени Past Simple [4, стр.2].

Эффект ускорения времени может быть также достигнут путем использования глаголов движения быстрого темпа. Снова увеличившись в размерах, и получив возможность достать со стола золотой ключик, Алиса бежит к двери, ведущей в сад. Автор при этом использует глагол «hurry off» [4, стр. 16]. При описании белого кролика, которого Алиса так тщетно пытается догнать, употреблены в большинстве случаев глаголы движения быстрого темпа: «to trot along», «hurry on». В следующих примерах происходит еще больше ускорение темпа глаголов: «to run with all speed», «skurried away as hard as he could». 
Динамичная смена эпизодов также показана посредством использования темпоральных маркеров. Среди них в основном присутствуют слова и выражения, указывающие на внутреннюю соотнесенность событий в произведении («At that time...», «In another moment...», «After a few minutes...», «At this moment...» и другие).

Само время у Льюиса Кэрролла представлено живым. Автор его олицетворяет, наделяя чертами, присущими человеку. Например, в эпизоде, в котором Алиса садится к Шляпе, Зайцу и Соне за стол, герои говорят о времени как о человеке: «...you never even spoke to Time!», «If you knew Time as well as I do...», «He (Time) won’t do a thing I ask» [4, стр. 101-103]. Время обижается на Зайца за то, что он впустую тратит его (время), поэтому замирает на шести часах вечера, из-за чего этой необычной компании приходится все время только и делать, что пить чай. Кроме того, слово «время» является в данном произведении именем собственным, так как пишется с заглавной буквы, что также показывает стремление автора наделить его чертами, присущими одушевленным предметам, словно оживляя его.

Проанализировав средства выражения времени в произведении Льюиса Кэрролла мы пришли к выводу, что время бесконечно, обратимо, имеет достаточно размытые границы. Автор прибегает к нарушению временной последовательности, замедляя время при помощи наречий (slowly, plenty, heavily и др.) и видо-временных форм глагола, преимущественно Past Continuous. Ускорение времени достигается за счет наречий (rapidly, hastily, hurriedly и др.), глаголов движения быстрого темпа (hurry off, trot along, hurry on, run with all speed, skurry away), перехода глаголов из Past Continuous в Past Simple, а также темпоральных маркеров. Приемы замедления и ускорения времени позволяют автору передать динамичность, создать эффект быстрой смены разных эпизодов. Таким образом, можно выделить основные средства, выражающие время в данном рассказе: наречия, система видо-временных форм глагола и их последовательность, глаголы движения быстрого темпа, темпоральные маркеры, а также такая стилистическая фигура, как олицетворение.

Список литературы:

1. Гальперин И.Р. Текст как объект лингвистического исследования [Текст] / И.Р. Гальперин. М.: КомКнига, 2006. - С. 53-65.

2. Енукидзе Р.И. Художественный хронотоп и его лингвистическая организация [Текст] / Автореф...канд. филол. наук. - Тбилиси, 1984. - С. 10-15.

3. Николина Н.А. Филологический анализ текста: учеб. пособие для студ. высш. пед. учеб. заведений / Н. А. Николина. - 3-е изд., стер. - М.: Академия, 2008. - С. 122130.

4. Lewis Carroll. Alice's adventures in Wonderland. Chicago, Illinois, 1998. Vol.1. P. 1-105. URL: https://www.adobe.com/be_en/active-use/pdf/Alice_in_Wonderland.pdf 